\title{
“The Sleeping Dragon Is Gathering Strength": Causes of Sinophobia in Central Asia
}

\section{Catherine Owen}

\begin{abstract}
In order to explore the roots of contemporary Sinophobia in Central Asia, this article combines historical analysis with ethnographically informed interviews. It shows that Sinophobia is widely spread through conspiracy theories especially in Kyrgyzstan and Tajikistan. Based on the territorial acquisitions made by China in the immediate post-Soviet period, conspiracy theories suggest that China is planning to "take over" Central Asia. However, a diachronic view of relations between China and Central Asian states demonstrates that these acquisitions were part of an attempt to resolve colonial disputes dating back to the late 19th century, and that China has already significantly reduced its territorial claims. Fears of contemporary Chinese territorial expansion are therefore greatly exaggerated. This article concludes by endorsing a proactive stance on tackling Sinophobia in Central Asia, both for the Chinese government and
\end{abstract}

Catherine Owen is Lecturer in Central Asian Studies at Shaanxi Normal University, China, and Research Fellow at the University of Exeter, UK. Her mailing address is 80 Sandford Walk, Exeter, EX1 2ET, United Kingdom. She can also be reached at C.A.M. Owen@exeter.ac.uk

The fieldwork presented in this article was conducted through the UK-based Economic and Social Research Council research project "Rising Powers and Conflict Management in Central Asia" (ES/J013056/1).

(C) 2017 World Century Publishing Corporation and Shanghai Institutes for International Studies China Quarterly of International Strategic Studies, Vol. 3, No. 1, 101-119

DOI: 10.1142/S2377740017500063 
for regional states. Other than the many economic initiatives it funds in Central Asia, China must put more efforts to enhance its soft power so as to assuage the century-long Sinophobia in the region.

Keywords: Sinophobia; Central Asia; conspiracy theory; regional integration.

\section{Introduction: Conspiracy Theories and Sinophobia in Central Asia}

As the regional influence of other large powers decline, China has opportunities to forge stronger relationships with the five post-Soviet Central Asian states: Kazakhstan, Kyrgyzstan, Tajikistan, Turkmenistan, and Uzbekistan. U.S. presence has been decreasing since 2005 when its military was evicted from the Karshi-Khanabad air base, Uzbekistan. Its diminished status was cemented in 2014 when it vacated its last military base in Central Asia, namely Manas International Airport in Kyrgyzstan. Russian influence has also declined since the collapse of the USSR - although cultural and linguistic ties remain strong, the weakened Russian economy and a growing sense of nationalism in the five post-Soviet states have led them to diversify their international ties. In particular, the ongoing crisis in Ukraine and accompanying Western sanctions have thwarted Russian investment in the region. ${ }^{1}$ By contrast, China, with its booming economy and generous loan packages, is becoming a popular ally at the government level, where bilateral agreements and generous investment programs indicate close interstate friendship. Indeed, Alexander Cooley has argued that China has proven itself "the most nuanced and skilled of the three great powers in its regional diplomacy." ${ }^{2}$

Yet, as this article demonstrates, there are tensions between China's relations with Central Asia at the non-official level. While Central Asian leaders declare their close relations with Beijing, with joint statements

\footnotetext{
${ }^{1}$ Peter Leonard, “Economy and Sanctions Derail Russia's Central Asian Investments," Eurasianet.org, January 28, 2016, http://www.eurasianet.org/node/77051.

${ }^{2}$ Alexander Cooley, Great Games, Local Rules: The New Great Power Contest in Central Asia (Oxford: Oxford University Press, 2012), p. 74.
} 
released to boost "strategic partnerships" and "mutual cooperation," conspiracy theories about the "real intentions" behind Chinese interests are rife. In addition, Chinese citizens living in Central Asia have been victims of violence and racism, and protests against perceived Chinese incursions into the region are not uncommon. For instance, a baseless but popular Kyrgyz saying goes that "When the black-haired Chinese turns up, the gingerbearded Russian will become dearer than your own father." Meanwhile, China has put forward a strategic vision for the region, the "Silk Road Economic Belt," that presupposes ever-closer integration. If China's plans are to succeed, the problem of Sinophobia must be addressed. For as Kemel Toktomushev has pointed out, "Sinophobia may emerge as one of the greatest obstacles for the Beijing-led regional integration." ${ }^{3}$

It would be easy to see Kyrgyzstan (population: 6 million) and Tajikistan (population: 8.5 million), Central Asia's poorest states, as pawns in the hands of their giant neighbors: the two economies are highly dependent on China, with significant amounts of trade, and on Russia, the primary destination for labor migrants. Yet analyses that present Central Asia as a "chessboard" upon which great powers play games ${ }^{4}$ miss important aspects of the region's international relations - Kyrgyzstan and Tajikistan remain independent actors with the capacity to shape international alliances $^{5}$ and subvert hegemonic projects. ${ }^{6}$ As Sebastian Peyrouse has noted, Central Asian states "should not be taken as mere passive objects in a game between great powers, but as actors in their own right that have wellestablished opinions on what they want to obtain from China, and any other country." ${ }^{7}$ Accessing and contextualizing these opinions is therefore central to an understanding of the ways in which these states act vis-à-vis

${ }^{3}$ Kemel Toktomushev, “The Silk Road Economic Belt's Impact on Central Asia," ChinaUS Focus, May 8, 2015, http://www.chinausfocus.com/finance-economy/the-silk-road_economic-belts-impacts-on-central-asia/.

${ }^{4}$ Zbigniew Brzezinski, The Grand Chessboard: American Primacy and Its Geostrategic Imperatives (New York: Basic Books, 1997).

${ }^{5}$ Cooley, Great Games, Local Rules: The New Great Power Contest in Central Asia.

${ }^{6} \mathrm{~J}$. Heathershaw and Catherine Owen (in preparation), "Is Post-Western IR Postcolonial? Mimicry and Mētis of Russia in Central Asia."

${ }^{7}$ Sébastien Peyrouse, "Discussing China: Sinophilia and Sinophobia in Central Asia," Journal of Eurasian Studies, Vol. 7, No. 1 (January 2016), pp. 14-23. 
their two large neighbors, and is key to predicting future trends and challenges.

This article is based on the assumption that an understanding of the roots of contemporary Sinophobia in Central Asia may help efforts to address it. It is based on 15 semi-structured interviews and one focus group with members of political and cultural elites in Bishkek, capital of Kyrgyzstan, and Dushanbe, capital of Tajikistan, between November 2013 and June 2015 on the subject of the growing influence of China in the region. The analysis shows that Sinophobia is propagated in a number of conspiracy theories exploiting deep-seated fears of land acquisition by the Chinese, which are widely held and occasionally result in violence against ethnic Chinese in the region. Although Central Asian states did cede land to China in the early post-Soviet period, it was part of an attempt to resolve colonial disputes dating back to the late 19th century, and China has already significantly reduced its territorial claims. Fears of contemporary Chinese territorial expansion are thus greatly exaggerated.

According to Sunstein and Vermeule, conspiracy theories can be defined as "an effort to explain some event or practice by reference to the machinations of powerful people, who attempt to conceal their role (at least until their aims are accomplished)." ${ }^{8}$ As discussed below, political instability and economic woes in Kyrgyzstan and Tajikistan are frequently blamed on a secretive, "cunning" ${ }^{9}$ China that is planning to merge the region into a vast western province. In a special section on conspiracy theories in the post-Soviet space

Sinophobia is widespread among the Central Asian public despite close governmental relations between

China and regional states. published in The Russian Review, John Heathershaw has classified this kind of conspiracy theory as a "foreign threat" theory; however, his analysis only focuses on the treacherous hand of the

${ }^{8}$ Cass R. Sunstein and Adrian Vermeule, “Conspiracy Theories: Causes and Cures," Journal of Political Philosophy, Vol. 17, No. 2 (June 2009), pp. 202-227.

${ }^{9}$ Focus group, four social scientists, Bishkek, June 2015. 
Russian "older brother."10 In the same special section, Marlene Laruelle argues that conspiracy theories in the post-Soviet space should be linked to the political and social upheavals of the Soviet collapse. ${ }^{11}$ Nonetheless, this article goes further to link specifically Sinophobic conspiracy theories to the unequal treaties of the late 19th century and the anti-Chinese discourse produced by the USSR following the Sino-Soviet split.

The article begins by examining Chinese-Central Asian relations during the late imperial period, during the Sino-Soviet split, and in the immediate post-Soviet period. The second section presents some of the most common grievances as expressed by respondents, and highlights notable acts of violence and protests against Chinese in Central Asia. The third section gives a brief summary of the recent expansion of Chinese activities in order to provide background to the rise of Chinese presence in the region. It concludes with the opinion that although Central Asia is a region particularly susceptible to conspiracy theories, there are a number of steps that can be taken both by China and the governments concerned, in order to effectively address Sinophobia.

\section{A Century of Suspicion: From the Age of Empire to Soviet Collapse}

It is a main argument of this article that the history of relations between the Central Asian region and China in the 19th and 20th centuries can provide important insights into the roots of contemporary Sinophobia. Many of the fears expressed by respondents in the following section have evolved and escalated because of events, rumors and stories relating to these periods. In particular, during the 19th century, China's western border between Xinjiang and the rest of the Central Asian region was weak and porous until the establishment of the USSR, which enabled much give-and-take between the various empires and warlords that had been active on Central Asia's open lands. Later, during the 20th century, the Sino-Soviet split fueled the

${ }^{10}$ John Heathershaw, "Of National Fathers and Russian Elder Brothers: Conspiracy Theories and Political Ideas in Contemporary Central Asia," Russian Review, Vol. 71, No. 4 (October 2012), pp. 610-629.

${ }^{11}$ Marlène Laruelle, "Conspiracy and Alternate History in Russia: A Nationalist Equation for Success?," Russian Review, Vol. 71, No. 4 (October 2012), pp. 565-580. 
proliferation of anti-Chinese propaganda in Central Asia by the USSR, as well as attempts to stir up unrest across the border in Xinjiang. This section details the issues that emerged in China during these two periods before discussing China's attempts to resolve them in the aftermath of the Soviet collapse.

During the 19th century, the Russian Empire signed a series of treaties with the Qing Dynasty, which the latter perceived to be deeply unfair. Particularly relevant to Central Asia is the Treaty of St. Petersburg (1881), which allowed Russians to set up consuls in Xinjiang across the border from what is now Kazakhstan in order to enhance trade and delimit the SinoRussian boundary in Central Asia. ${ }^{12}$ However, Chinese armies had also explored westward, and had advanced as far as Yashil Kul (in present-day Tajikstan's Gorno-Badakhshan Autonomous Province) by 1759. Indeed, that the Kokand Khanate (now Uzbekistan) had paid tribute to the Qing Dynasty until 1798 demonstrates precisely the fluid nature of claims and loyalties in this region during the imperial era.

In order to understand Chinese territorial claims made after the Soviet collapse, it is important to study the interactions between the Chinese and Russian Empires in the region in more detail. During the 1860s, Yaqub Beg, a warlord from the Kokand Khanate invaded Chinese-held Kashgar and took control of most of what is now Xinjiang. The region remained in Beg's hands until 1877, when Chinese forces killed Beg and regained control. ${ }^{13}$ Recalling the fort at Yashil Kul, the Chinese claimed that Beg's dominion had extended as far as Gorno-Badakhshan and thus, the whole region now belonged to them. ${ }^{14}$ After several stand-offs between Chinese and Russian armies in the Pamir Mountains, in 1884 the two empires signed an additional protocol to the Treaty of St. Petersburg, which sought to define boundary limits. However, the details of the borderlines were imprecise and the treaty effectively created a no-man's land that spread across much of the Pamir Mountains. The Pamir question was not settled until 1894,

${ }^{12}$ Eric Hyer, The Pragmatic Dragon: China's Grand Strategy and Boundary Settlements (Seattle: University of Washington Press, 2015).

${ }^{13}$ Peter B. Golden, Central Asia in World History (Oxford: Oxford University Press, 2011), p. 126.

${ }^{14}$ John W. Garver, “The Sino-Soviet Territorial Dispute in the Pamir Mountains," China Quarterly, Vol. 85 (March 1981), pp. 107-118. 
when China wanted Russia to help against the Japanese in Korea and acquiesced to the Russians' terms. ${ }^{15}$

In the years following the overthrow of the Russian Empire by the Bolsheviks, Central Asia was absorbed into the USSR. For most of the 20th century, relations between the two Communist states were poor. The SinoSoviet split brought the problem of territorial integrity and potential ethnic separatism into the spotlight. ${ }^{16}$ During the 1950s, many Uighurs from Xinjiang had migrated to the Kazakh and Kyrgyz Soviet Social Republics (SSRs) and to Russia. However, in the late 1950s, fearing territorial disunity, Chinese authorities forbade contact between the Uighurs in Soviet Central Asia and those in Xinjiang. ${ }^{17}$ Skirmishes along the border grew more frequent as relations declined, in particular with the Kazakh SSR and Tajik SSR. During the 1960s, China began to militarize the Xinjiang region, installing five infantry divisions, two to three division-equivalents of border guards, artillery regiments attached to each division, as well as paramilitary units known as the Production and Construction Corps. ${ }^{18}$

China's fears of territorial disunity during the mid-20th century were not unfounded. Soviet policy toward the Uighurs was considerably more generous than toward other ethnic minorities and, during the 1960s, as Sino-Soviet relations deteriorated, the Soviet press in Central Asia ran a large number of polemical stories contrasting the happy life of Uighurs in the USSR with those in neighboring Xinjiang. A radio station called Free Sinkiang (Xinjiang) reportedly operated from the Kazakh SSR and was broadcast across the Chinese border, and programs in Uighur language extolling the USSR were broadcast from Almaty and Tashkent. As ŠildeKārklinš argues, the Soviets used the Uighur question in an attempt to undermine Chinese territorial integrity. ${ }^{19}$ Further, virulent anti-Chinese

${ }^{15} \mathrm{Ibid}$

${ }^{16}$ Raphael Israeli, "The Muslim Minority in the People's Republic of China," Asian Survey, Vol. 21, No. 8 (August 1981), pp. 901-919.

${ }^{17}$ Rasma Šilde-Kārklinš, "The Uighurs Between China and the USSR," Canadian Slavonic Papers, Vol. 73, No. 2/3 (2015), pp. 341-365.

${ }^{18}$ Thomas W. Robinson, “The Sino-Soviet Border Dispute: Background, Development and the March 1969 Clashes," American Political Science Review, Vol. 66, No. 4 (December 1972), pp. 1175-1202.

19Šilde-Kārklinš, “The Uighurs Between China and the USSR.” 
propaganda was spread widely throughout the region, ${ }^{20}$ which no doubt shaped the views of a generation of Central Asians regarding China.

In the aftermath of the Soviet collapse, the main priority for China vis-à-vis the new Central Asian states was to address the problems that had built up during the past century: the political unrest in Xinjiang and the border issues that stemmed from the "unequal" treaties. Regarding the first problem, China signed bilateral agreements with each newly independent state and created a re-

Sinophobia in

Central Asia is

largely a result of

Sino-Russian

tensions in the 19th and 20th centuries. gional security organization called the "Shanghai Five" (which later became the Shanghai Cooperation Organization discussed in the third section below). The second problem required more sensitive maneuvering and, in order to ensure regional cooperation in the field of anti-separatism, China greatly reduced its territorial claims. ${ }^{21}$

In the case of Kazakhstan, Kazakh President Nazarbayev and Chinese Premier Li Peng signed boundary agreements in 1994, 1997 and 1998, which ceded 34 percent of the 2,420 square kilometers that China had initially claimed. ${ }^{22}$ In the case of Kyrgyzstan, China also dropped claims to most of its disputed land, receiving just over a third of the 3,635 square kilometers it had initially requested. ${ }^{23}$ In the case of Tajikistan, the Pamir Mountains remained a source of contention as China initially claimed nearly all of Gorno-Badakhshan. ${ }^{24}$ Border disputes between the two countries were not resolved until 2011, when Tajikistan ceded 1,142 square kilometers to China (significantly lower than the 28,500 square kilometers initially requested). ${ }^{25}$

${ }^{20}$ Charles Dobbs and Charles M. Dobbs, Triangles, Symbols and Constraints: The United States, the Soviet Union and the People's Republic of China, 1963-1969 (Lanham: University Press of America, 2010).

${ }^{21}$ Dru C. Gladney, “Islam in China: Accommodation or Separatism?,” China Quarterly, No. 174 (June 2003), pp. 451-467.

${ }^{22}$ M. Taylor Fravel, Secure Borders, Strong Nation: Cooperation and Conflict in China's Territorial Disputes (Princeton: Princeton University Press, 2008), p. 162.

${ }^{23}$ Ibid., p. 163.

${ }^{24}$ Ibid., p. 166.

25 “Tajikistan: China's Advance Causing Increasing Unease Among Tajiks,” Eurasianet. org, February 14, 2011, http://www.eurasianet.org/node/62894. 
In this way, the matter of the "unequal treaty" of St. Petersburg was finally brought to a close.

Although China received diplomatic recognition from Central Asian leaders that the 19th-century treaties were unfair, domestic populations were deeply unhappy about the ceding of land to China. Particularly in Kyrgyzstan, there has been strong anti-Chinese sentiment at the government level since the early 2000s, when a bilateral agreement regarding border delimitations was secretly signed by then-President Akayev without consulting the parliament. Kyrgyz officials discovered in 2001 that Kyrgyzstan would cede an extra 95,000 hectares of land to China, and immediately interrupted the demarcation process. Although the agreement was ratified in the following year amid protests across the country, ${ }^{26}$ it still came back to haunt Akayev in 2005 following the "Tulip Revolution," when the acting president and presidential candidate, Kurmanbek Bakiev, accused him of selling the country off to China. ${ }^{27}$

With this history in mind, it is perhaps not surprising that Central Asians are susceptible to the conspiracy theories discussed in the following section that claim China is preparing to dominate the region. Moreover, this diachronic view also contextualizes contemporary Chinese actions regarding the Central Asian border issues.

\section{"Waiting in Ambush like a Patient Asian Tiger" 28: A Closer Look at Sinophobia}

Although respondents generally viewed the economic aspect of Chinese presence in a positive light, many struggled with a deep-rooted fear of their large neighbor, instilled from infancy and sustained by a lack of knowledge about the Chinese culture in general and its intentions in

${ }^{26}$ Yitzhak Shichor, “The Great Wall of Steel: Military and Strategy in Xinjiang," in S. Frederick Starr, ed., Xinjiang: China's Muslim Borderland (New York: M.E. Sharpe, 2004).

${ }^{27}$ Cooley, Great Games, Local Rules: The New Great Power Contest in Central Asia, p. 80.

${ }^{28}$ Interview, journalist from Radio Free Europe, Bishkek, June 2015. It must be emphasized, however, that the views expressed by respondents in Kyrgyzstan and Tajikistan may not be shared by citizens in Uzbekistan and Turkmenistan, as no research has been conducted on this subject in these countries. There is some evidence to suggest they are shared by those in Kazakhstan, as this section of the article makes clear. 
Central Asia in particular. One Bishkek resident explained, "In my childhood, if we didn't eat the food that our grandmother prepared, she would scare us by saying that the Chinese will come." ${ }^{29}$ Such Sinophobia manifests itself primarily in the form of conspiracy theories and the perpetuation of negative stereotypes, but it occasionally erupts in the form of violence and protests.

Conspiracy theories of Chinese intentions in Central Asia abound both online and in face-to-face discussions, most of which consist of variations on the idea that China wants to "take over" Central Asia. For instance, development assistance given by China to the south of Kyrgyzstan, in the form of hospital equipment and televisions, was seen as "all part of a plot to exploit some piece of land in Osh that the Chinese know about and that others do not." ${ }^{30}$ Other conspiracy theories centered on the possibility of China's subtle hand in local conflicts. For instance, some believed that the 2010 riots were fueled by the Chinese closing their borders, ${ }^{31}$ while others thought that the unrest in Tajikistan's Gorno-Badakhshan region was driven by China. ${ }^{32}$ Another theory frequently encountered during the research proposed that Russia and China are planning to take over the region together, with Russia providing the security and China the finance. ${ }^{33}$ One respondent illustrated the way in which anti-Chinese sentiment is whipped up on social media. He recounted the furious sharing of an image of 30 Muslim men doing exercises, with a caption underneath stating that Chinese authorities force Muslims to exercise during Ramadan, a month of fasting for Muslims worldwide, while forbidding them to pray. The respondent tried to find the source of this photograph, only to discover that it was fake. ${ }^{34}$

Furthermore, some people believe that the increase of Chinese immigrates to Central Asian countries is due to encouragement from the Chinese

${ }^{29}$ Interview, journalist from Radio Free Europe, Bishkek, June 2015.

${ }^{30}$ Interview, OSCE employee, Bishkek, November 2013.

${ }^{31}$ Ibid.

${ }^{32}$ Interview, European External Action Service employee, Dushanbe, November 2013.

${ }^{33}$ Focus group, four social scientists, Bishkek Humanities University, Bishkek, June 2015; and interview, U.S. Embassy staff, Dushanbe, November 2013.

${ }^{34}$ Interview, journalist from Radio Free Europe, Bishkek, June 2015. 
government and illegal border crossings. ${ }^{35}$ Many respondents feel that the immigration is "out of control," and that Chinese men arrive in Central Asia with the aim of marrying local women to thereby "dilute" the region ${ }^{36}$ or becoming a "fifth column" that advances Chinese interests. ${ }^{37}$ Some believe that Kyrgyzstan and Tajikistan will eventually become the People's Republic of China (PRC)'s most western province. ${ }^{38}$ In the words of one respondent, "they will choke us in their hug." 39

The saliency of these conspiracy theories is fueled by a lack of knowledge both of China's foreign policy goals and of its culture and way of life. In particular, respondents did not understand the reasons for China's overwhelming generosity, and suspected self-interested or even nefarious reasons behind the magnanimous appearance. As one respondent stated, "The question people always seem to return to is what is it that the Chinese are getting in exchange for their investments. There is not that much in Kyrgyzstan." ${ }^{40}$ Others appeared to know little about life in China, perceiving it as a "backward place without any electricity." ${ }^{41}$ Another claimed that Chinese workers in Central Asia do not attempt to integrate, "The problem is the Chinese coming is something that expresses itself in the creation of alternate and parallel societies rather than anything that is very coherent and independent. They all speak Chinese to each other, making hard for outsiders to get in and participate. ${ }^{\prime 2}$ Similarly, another respondent complained about

${ }^{35}$ Ainur Nogayeva, “Limitations of Chinese 'Soft Power' in Its Population and Language Policies in Central Asia," Geopolitics, Vol. 20, No. 3 (2015), pp. 583-605.

${ }^{36}$ Focus group, four social scientists, Bishkek Humanities University, Bishkek, June 2015; interview, journalist from Radio Free Europe, Bishkek, June 2015; interview, freelance journalist, Bishkek, June 2015; and interview, academic at the Department of KyrgyzChinese Studies, Bishkek Humanities University, Bishkek, June 2015.

${ }^{37}$ Focus group, four social scientists, Bishkek Humanities University, Bishkek, June 2015.

${ }^{38}$ Interview, Center for Strategic Studies under the President, Dushanbe, November 2013; interview, journalist from Vecherniy Bishkek, Bishkek, June 2015; and focus group, four social scientists, Bishkek Humanities University, Bishkek, June 2015.

${ }^{39}$ Focus group, four social scientists, Bishkek Humanities University, Bishkek, June 2015.

\footnotetext{
${ }^{40}$ Interview, diplomat, Bishkek, November 2013.

${ }^{41}$ Interview, traders in Dordoi market, Bishkek, November 2013.

${ }^{42}$ Interview, OSCE Academy employee, Bishkek, November 2013.
} 
the constant exclusion of Tajik workers from Chinese projects in their country, explaining that Chinese companies would claim that local workers were not qualified to work on their projects, and thus the locals were left unemployed and unable to benefit from Chinese economic activities. ${ }^{43}$

Unfortunately, this suspicion translates itself occasionally into violence against Chinese in Central Asia. Numerous interviewees could recall stories of clashes between Chinese businesses or entrepreneurs and local groups. ${ }^{44}$ Others stated that small-scale Chinese projects are targets for local criminal gangs, and Chinese businesses are sometimes victims of arson. ${ }^{45}$ One Tajik respondent recalled five occasions in one year when a Chinese man married a local woman, and each time led to violence against the man in question. ${ }^{46}$ Some incidents of violence made headlines in the regional media, and even beyond. In July 2013, Guan Ju Chang, a Chinese owner of a chain of optician stores in Bishkek, was murdered under suspicious circumstances. ${ }^{47}$ Later in the same year, there was a series of inter-ethnic scuffles between ethnic Dungan truck drivers and local Kyrygz groups at the Torugart Pass on the China-Kyrgyz border in Naryn Province. ${ }^{48}$ In December 2014, a group of men from the nationalist organization Kyryk

\footnotetext{
${ }^{43}$ Interview, International Organization for Migration employee, Dushanbe, November 2013. See also Bruce Pannier, "Tajikistan Agrees to Allow Chinese Farmers to Till Land," Radio Free Europe/Radio Liberty, January 28, 2011, http://www.rferl.org/a/tajikistan_china/ 2289623.html.

${ }^{44}$ Interview, former students at American University of Central Asia, Bishkek, November 2013; interview, diplomat, Bishkek, November 2013; interview, OSCE Academy employee, Bishkek, November 2013; interview, traders in Dordoi market, Bishkek, November 2013; and focus group, four social scientists, Bishkek Humanities University, Bishkek, June 2015.

${ }^{45}$ Interview, Chinese businessman, Bishkek, November 2013; and interview, freelance journalist, Bishkek, June 2015.

${ }^{46}$ Interview, Center for Strategic Studies under the President, Dushanbe, November 2013.

${ }^{47}$ Vercherniy Bishkek, “Kto ubil vladel'tsa magazinov 'Fujin'?," Vecherniy Bishkek, July 31, 2013, http://members.vb.kg/2013/07/31/panorama/1.html.

${ }^{48} \mathrm{Kim}$, A., "Eksklyusiv: Pochemu voditeli-dungane boyatsya peresekat Narynskuyu Oblast," Kloop.kg, November 1, 2013, http://kloop.kg/blog/2013/11/01/voditeli-dunganeboyatsya-peresekat-nary-nskuyu-oblast-iz-za-napadenij-na-e-tnicheskoj-pochve/; focus group, four social scientists, Bishkek Humanities University, Bishkek, June 2015; and interview, journalist from Radio Free Europe, Bishkek, June 2015.
} 
Choro raided a Chinese karaoke club in Bishkek, accusing the Chinese women of being prostitutes and the men of "abetting vice" in Kyrgyzstan. ${ }^{49}$ Most recently, in August 2016, a suicide bomber blew himself up at the Chinese Embassy in Bishkek; at the time of writing, neither organizers nor motives for the attack have been determined. ${ }^{50}$

\section{Conspiracy theories often trigger protests and even violence against Chinese in some Central Asian} countries.

The disquiet surrounding the growing presence of China in the region has occasionally manifested itself on the streets in the form of occupations and demonstrations. In 2013, protesters in Osh, Kyrgyzstan closed a Chinese-owned goldmine, ${ }^{51}$ and in 2016, protests against land reforms in several cities across Kazakhstan were driven by fears of Chinese takeover. ${ }^{52}$ The protests were particularly surprising in the case of Kazakhstan, as it is a country that typically sees very low levels of public dissent. In order to provide some context for the level of Sinophobia presented here, the following section gives an overview of contemporary Chinese activities in Central Asia.

\section{Advancing the "Shanghai Spirit": China in Central Asia Today}

Since the new millennium, China's engagement with Central Asia has rapidly increased, especially in the following four aspects. First, it has attempted to diversify its energy sources - compared with politically volatile countries in the Middle East and Africa, Central Asia represents a more

${ }^{49}$ Anna Lelik, "Kyrgyzstan: Nationalist Vice Squad Stirs Controversy," Eurasianet.org, February 10, 2015, http://www.eurasianet.org/node/71996.

50 “Kyrgyzstan: Chinese Embassy Attack Still Mired in Mystery," Eurasianet.org, October 5, 2016, http://www.eurasianet.org/node/80821.

51 "Chinese Mining Company Operations in Kyrgyzstan Blocked by Protesters," Radio Free Europe/Radio Liberty, May 16, 2013, http://www.rferl.org/a/chinese-mining-companyoperations-kyrgyzstan-blocked-protesters/24987866.html.

52 “Kazakhstan's Land Reform Protests Explained," BBC News, April 28, 2016, http:// www.bbc.co.uk/news/world-asia-36163103; and Aziz Burkhanov and Yu Wen Chen, "Kazakh Perspective on China, the Chinese and Chinese Migration," Ethnic and Racial Studies, Vol. 39, No. 12 (2016), pp. 2129-2148. 
stable and more convenient source of energy for China's growing domestic markets. Second, it has sought closer bilateral ties with all the five Central Asian states, increasing trade and investment, with the aim of ensuring a stable and prosperous Central Asia that would not contribute to tensions in the restive neighboring Xinjiang Province. Third, it has advanced closer regional integration by promoting regional security-oriented intergovernmental organizations such as the Shanghai Cooperation Organization (SCO), and infrastructural projects, notably the "Silk Road Economic Belt (SREB)." Fourth, it has sought to promote greater understanding of Chinese culture through various soft power initiatives. This section briefly considers each of these aspects.

Over the last decade, China has pursued a number of energy projects in the region. Since 2009, China has been jointly developing the Galkynysh gas fields in Turkmenistan, the second largest in the world. According to the BP Statistical Review of World Energy, nearly all of China's imported gas came from Turkmenistan in 2015. ${ }^{53}$ China and Kazakhstan have cooperated on the construction of an oil pipeline that runs from Kazakhstan's western oilfields to the Dushanzi oil refinery in China's Xinjiang Province. In 2014, Kazakhstan was China's 11th largest oil exporter, accounting for about 2 percent of total imports. ${ }^{54}$ China has assisted in the construction of the Central Asia-China gas pipeline, an ambitious network of four pipes, three of which are already in operation, that links the region's natural gas reserves with Xinjiang.

At the same time, China has become a major economic actor in Central Asia, already bypassing Russia in $2008 .{ }^{55}$ A key driver behind this policy is fears of political instability in Xinjiang, which shares a 3,300 km-long border with Kyrgyzstan, Tajikistan and Kazakhstan, and the accompanying belief that economic development will quell unrest. ${ }^{56}$ As of 2015, China was the

${ }^{53}$ British Petroleum, “Statistical Review of World Energy 2015," http://www.bp.com/ en/global/corporate/energy-economics/statistical-review-of-world-energy.html.

${ }^{54}$ Statistica, "Breakdown of China's Crude Oil Imports in 2014, by Source Country," Statistica.com, https://www.statista.com/statistics/221765/chinese-oil-imports-by-country/.

${ }^{55}$ Cooley, Great Games, Local Rules: The New Great Power Contest in Central Asia.

${ }^{56} \mathrm{Hu}$ Weixing, “China's Central Asia Policy: Making Sense of the Shanghai Co-operation Organization," in Boris Rumer, ed., Central Asia at the End of Transition (London: Routledge, 2005). 
second largest trading partner with Kyrgyzstan after Russia, ${ }^{57}$ driven by Kyrgyzstan's ascension to the Eurasian Economic Union. ${ }^{58}$ In Tajikistan, China was the third largest trading partner in $2014 .{ }^{59}$ Meanwhile, loans from the Chinese government account for a third of Kyrgyzstan's and nearly half of Tajikistan's sovereign debt. ${ }^{60}$ Given the level of poverty in Central Asia - the Tajik and Kyrgyz economies are the most remittance dependent in the world ${ }^{61}$ - it is not surprising that local governments have embraced Chinese investment, despite the high levels of unease among the domestic population. However, it is important to put Chinese interests in Central Asia in perspective: approximately two thirds of China's trade is conducted with advanced economies alone. ${ }^{62}$

Building on this longstanding investment in the region, Chinese President Xi Jinping announced the "Belt and Road" Initiative in 2013, which would promote a new "Silk Road Economic Belt," comprising transport infrastructure and logistical hubs, through the region in order to connect Chinese and European markets via Central Asia. Given the many ongoing investments in the form of roads, railways and other infrastructural works, it is hard to isolate particular projects as belonging to the SREB. However, the Khorgos Gateway, a cargo hub on the China-Kazakhstan border occupying a key position on the SREB, began operations in August 2015. According to the Beijing-based Asian Infrastructure Investment Bank (AIIB), created in 2015 with the aim of financing projects related to the "Belt and Road" Initiative, approximately 750 billion dollars a year have been

57 “China Becomes Kyrgyzstan's Second Largest Investor,” Xinhua News, August 22, 2016, http://news.xinhuanet.com/english/2016-08/22/c_135625176.htm.

${ }^{58}$ Anna Lelik, “Kyrgyzstan: Bishkek Hopes Chinese Investment Can Produce Industrial Breakthrough," Eurasianet.org, June 22, 2016, http://www.eurasianet.org/node/79346.

59 “China, Tajikistan Sign Currency Swap Deal to Bolster Trade," Xinhua News, September 7, 2015, http://news.xinhuanet.com/english/2015-09/07/c_134598741.htm.

${ }^{60}$ Chris Rickleton, "Are Chinese Investors Ditching Kyrgyzstan for Tajikistan?," Eurasianet.org, January 20, 2015, http://www.eurasianet.org/node/71696.

${ }^{61}$ David Trilling, "Remittances to Central Asia Fall Sharply, as Expected," Eurasianet. org, April 21, 2015, http://www.eurasianet.org/node/73061.

${ }^{62} \mathrm{IMF}$, “Direction of Trade Statistics: China 2015," http://data.imf.org/?sk=9D6028D4F14A-464C-A2F2-59B2CD424B85\&ss=1454702198568. 
earmarked for infrastructural projects in related regions (including in Central Asia) through to $2020 .{ }^{63}$

In terms of diplomacy, all five Central Asian states are now in a bilateral strategic partnership with China, "the highest of diplomatic epithets." 64 They are also members of the SCO, comprising China, Russia and all post-Soviet Central Asian states, apart from Turkmenistan. Founded in 2001 with the aim of countering terrorism, separatism and ex-

China is increasingly active in promoting comprehensive engagement with Central Asia. tremism in the region, the SCO has consolidated border security regimes among its members and formalized commitments to preserving regional stability. It has also created a $\$ 10$ billion fund financed solely by China in order to support infrastructure initiatives in Central Asia. This is larger than all the other international donors in the region (for instance, the World Bank, the European Bank for Reconstruction and Development and the Asian Development Bank), and "establishes China as the region's leading external donor." ${ }^{15}$ The SCO is often perceived by Western observers as a legitimizing tool for China's activities in Central Asia, and for the preservation of its "non-democratic rule;" 66 yet non-Western observers see it as an important vehicle for establishing multi-polarity in the international system. ${ }^{67}$

63"Spotlight: Three Years on, China's Belt and Road Initiative to Embrace Greater Achievements," Xinhua News, September 26, 2016, http://news.xinhuanet.com/english/ 2016-09/26/c_135715293.htm.

${ }^{64}$ Marlène Laruelle and Sébastien Peyrouse, China as a Neighbor: Central Asian Perspectives and Strategies, Central Asia-Caucasus Institute \& Silk Road Studies Program Report (Washington, D.C.: Johns Hopkins University, 2009), p. 14.

${ }^{65}$ Cooley, Great Games, Local Rules: The New Great Power Contest in Central Asia, p. 90.

${ }^{66}$ Thomas Ambrosio, "Catching the 'Shanghai Spirit': How the Shanghai Cooperation Organization Promotes Authoritarian Norms in Central Asia," Europe-Asia Studies, Vol. 60, No. 8 (2008), pp. 1321-1344; and Cooley, Great Games, Local Rules: The New Great Power Contest in Central Asia.

${ }^{67} \mathrm{Hu}$, “China's Central Asia Policy: Making Sense of the Shanghai Co-operation Organization"; Nadine Godehardt, The Chinese Constitution of Central Asia: Regions and Intertwined Actors in Central Asia (London: Palgrave MacMillan, 2014); and Nogayeva, "Limitations of Chinese 'Soft Power' in its Population and Language Policies in Central Asia." 
Aside from the energy, economic and diplomatic spheres, China has also attempted to enhance its image in the region through a number of projects that can be considered a means of building up "soft power." ${ }^{68}$ First, Confucius Institutes, government-funded public institutions affiliated with the Chinese Ministry of Education, have been founded throughout the region to promote Chinese language and culture. Currently, there are three Confucius Institutes in Kyrgyzstan, four in Kazakhstan, two in Tajikistan, and two in Uzbekistan. Second, China provides technical support and training to government departments. Kyrgyzstan's Interior and Foreign Ministries have received technical training, and staff have visited China for year-long language training programs. ${ }^{69}$ Likewise in Tajikistan, the Ministry of Defense is training employees in Mandarin with assistance from China. ${ }^{70}$ Third, Chinese state television, CCTV, is broadcast in Russian specifically for the countries of Central Asia and, according to reports, is very well received. ${ }^{71}$ Fourth, generous scholarships for study in Chinese universities are available to Central Asian youths. ${ }^{72}$ In Kyrgyzstan, joint degrees are offered in some universities which allow students to spend two years in China during their courses and receive degrees from both countries. $^{73}$

Overall, Chinese presence in Central Asia has increased dramatically in the past decade. This represents a relatively sudden change in regional dynamics from the Soviet and early post-Soviet periods when engagement was virtually non-existent. It is therefore not surprising that local people

${ }^{68}$ Bates Gill and Huang Yanzhong, "Sources and Limits of Chinese 'Soft Power,"' Survival, Vol. 48, No. 2 (June 2006), pp. 17-36; and David Shambaugh, “China's Soft Power Push: The Search for Respect," Foreign Affairs, Vol. 94, No. 4 (July/August 2015), pp. 99-107.

${ }^{69}$ Interview, U.S. diplomat, Bishkek, November 2013; and interview, former Kyrgyz foreign minister, Bishkek, November 2013.

${ }^{70}$ Interview, U.S. embassy staff, Dushanbe, November 2013.

${ }^{71}$ Interview, journalist from Radio Free Europe, Bishkek, June 2015; focus group, four social scientists, Bishkek, June 2015; and interview, journalist from Vecherniy Bishkek, Bishkek, June 2015.

${ }^{72}$ Bakirov, M., “'Sobiraetes' postupat v vuz v Kitae? Togda vpered!,” Radio Azattyk, June 3, 2015, http://rus.azattyk.org/a/27051381.html.

${ }^{73}$ Interview, academic at the Department of Kyrgyz-Chinese Studies, Bishkek Humanities University, Bishkek, June 2015. 
have been trying to make sense of these changes and that conspiracy theories constitute a part of that process.

\section{Conclusion: Easing Sinophobia in Central Asia}

This article has attempted to untangle some of the misperceptions of Chinese motives in Central Asia by contextualizing contemporary China's activities in their historical roots. It has argued that conspiracy theories regarding Chinese expansion into Central Asia extend from the border settlements of the immediate post-Soviet period, which attempted to right perceived historical wrongs of the Russian Empire during the 19th century. Furthermore, high levels of animosity between China and the USSR contributed to an ongoing suspicion of China's motives in the Central Asian republics. However, given that China and Central Asia will forever remain neighbors, it is in the interests of both China and the Central Asian governments to tackle the problem of Sinophobia.

One important starting point is probing into the reasons why people believe conspiracy theories. This is a subject of much debate. Sunstein and Vermeule have argued that individuals hold conspiracy theories as a result of a "crippled epistemology' in the form of a sharply limited number of (relevant) informational sources." ${ }^{74}$ They claim that two factors are important when considering whether a

China needs to further enhance its soft power while promoting economic initiatives in Central Asia. society might be predisposed to conspiracy theories. First, "closed societies" that lack freely available information from a diversity of sources are more likely to experience widespread beliefs in conspiracy theories, since it is much harder to challenge or disprove erroneous information. Second, low levels of trust in political and knowledgeproducing institutions are also likely to give rise to conspiracy theories, since citizens are less likely to believe anything officials say. Others have argued that the belief in conspiracy theories are symptomatic of a postmodern phenomenon of "deep anxiety of a widespread loss of agency,"

\footnotetext{
${ }^{74}$ Sunstein and Vermuele, "Conspiracy Theories: Causes and Cures," Journal of Political Philosophy.
} 
whereby individuals or groups attempt to reassert a modicum of power in the face of unstoppable forces of global change, and meaning in the face of information overload. ${ }^{75}$ One might consider Central Asia as suffering from all three problems: in most Central Asian countries, open debate in public is restricted; political institutions are held in low regard and corruption is rife; and the Soviet collapse left an ideological vacuum and a pervasive sense of meaninglessness.

Regarding concrete policy proposals, in the Western context, Sunstein and Vermeule argue that governments should publicly respond to more, rather than fewer, conspiracy theories, break up groups that actively promote them, and hire independent groups to supply rebut conspiracy theories. They also argue that a pluralistic public sphere is vital. Responding to the post-modern phenomenon of powerlessness is, unfortunately, harder to address in government policies. However, given the importance of conspiracy theories to maintaining the political status quo in post-Soviet politics, ${ }^{76}$ it is unlikely that addressing Sinophobic theories will be a priority for Central Asian governments. Nonetheless, China can attempt to clarify some of these historical misperceptions by expanding its soft power network.

Some Western commentators have argued that China does not have a clear plan for managing the political consequences of its growing economic role in Central Asia. ${ }^{77}$ In this regard, Central Asia appears as a launch pad for China's global strategy rather than an equal partner. Promoting transparency in China-Central Asian collaborations would be a good starting point for the demystification of Chinese intentions, and employing more Central Asian workers on Chinese projects would enable locals to enjoy tangible benefits of Chinese-led projects. All these efforts can help mitigate the century-long Sinophobia in Central Asia.

${ }^{75}$ Mark A. Fenster, Conspiracy Theories: Secrecy and Power in American Culture (Minneapolis: University of Minnesota Press, 2008); and Stefanie Ortmann and John Heathershaw, "Conspiracy Theories in the Post-Soviet Space," Russian Review, Vol. 71, No. 4 (2012), pp. 551-564.

${ }^{76}$ Andrew Wilson, Virtual Politics: Faking Democracy in the Post-Soviet World (Yale: Yale University Press, 2005); Heathershaw, "Of National Fathers and Russian Elder Brothers: Conspiracy Theories and Political Ideas in Contemporary Central Asia."

${ }^{77}$ Raffaello Pantucci, “China's Place in Central Asia,” Eurasianet.org, June 20, 2016, http://www.eurasianet.org/node/79306. 